\title{
REFLECTION
}

\section{What Do You Expect From a Doctor? Six Habits for Healthier Patient Encounters}

\author{
David Loxterkamp, MD \\ Seaport Family Practice, Belfast, Maine
}

AC Annals Journal Club selection, see inside back cover or www. annfammed.org/AJC/.

Conflict of interest: author reports none.

\section{CORRESPONDING AUTHOR}

David Loxterkamp, MD

Seaport Family Practice, PA

41 Wight St

Belfast, ME 04915

\begin{abstract}
Expectations lie at the heart of America's health care crisis. Although doctors cannot control for the unrealistic demands of a consumer-centric society, we might ask what we would want in a physician. Someone who listens longer and lets us express ourselves in our own words? Someone who cares about the outcome-our personal outcome-and not just the "clinical course"? Most patients do not demand perfection. Not cure. Not even relief, no matter what the TV commercials promise or how badly they wish them to be true. What we all desire is a plan that connects us to another human being-our doctor-which is a kind of relief all its own. The author identifies 6 simple habits that will lead to healthier, happier encounters with patients and their illness.
\end{abstract}

Ann Fam Med 2013;574-576. doi:10.1370/afm.1584.

\section{INTRODUCTION}

$\square$ xpectations lie at the heart of the American health care crisis. That's because we Americans expect a lot. As patients, we expect to live long, productive lives with replaceable joints, clear lenses, and revitalized hearts. We expect to receive a diagnosis and treatment for every complaint. We expect high-tech solutions for commonsense problems. We expect our doctors to be flawless and self-confident, and doctors, in turn, expect to be compensated for the stress of their relentless demands. Americans - or at least those with means - are said to enjoy the best health care system in the world, but even the most fortunate soon discover that health is a gift, as much dependent on genetics and good luck as it is on lifestyle choices and access to care.

When patients demand specific drugs, tests, or diagnoses, they prevent us from being a doctor - a professional whose training, skill, and dedication are put in the service of their recovery. Likewise, when we take a chief complaint at face value, our patients are short-changed. Neither patient nor doctor should expect the doctor to be a booking agent, approving parent, or frat brother. Yet bedside manner, face-to-face time, and a sense of connection - what we once unabashedly called the doctorpatient relationship - matter as much as the services that are delivered.

The son of my neighbor was brought to me with a high fever. The child was healthy in every other respect, so I advised a wait-and-see approach: clear liquids, ibuprofen, call if the condition worsens. I saw the boy each day thereafter and over the busy on-call weekend-his most worrisome findings morphing from uncontrolled fever to a loss of appetite, stiff neck, and enlarged lymph nodes. On Monday, I consulted the closest infectious disease specialist by telephone, but her tests proved inconclusive. The next night the boy developed pain with swallowing, and another on-call physician suggested a CT scan that revealed an abscess behind the boy's throat. He was hospitalized at the referral center and quickly recovered on intravenous antibiotics. 
Without a solid diagnosis or signs of improvement, the boy's parents and I were emotionally adrift, each of us swamped by our respective responsibilities and worries. I later admitted to the mother that her son's retropharyngeal abscess was the first I had seen in a child. I consoled myself in the belief that the delay in diagnosis caused no harm, but ruminated anyway on the boy's prolonged suffering, the mother's loss of trust in me, and the damage to my own self-confidence.

The 2 things that patients should expect from their doctor are competency, which diplomas and board certification attest to, and a moral compass that puts others' needs above the physician's. Beyond that, a few simple habits might assure that mutual satisfaction flows from the patient's encounter:

\section{IDENTIFY}

Patients need know to whom they are speaking-specifically, the health professional's level of training and responsibility. When continuity of care is challenged by after-hours coverage, urgent care visits, and the increasing presence of nurse practitioners, physician assistants, medical students, and residents-in-training, the patient may no longer recognize the "doctor" by sight or voice, and feel fortunate to see anyone at all. ${ }^{1}$

\section{Listen}

Patients want their doctors to listen and instinctively know that talk alone is therapeutic. ${ }^{2}$ Instead, doctors interrupt them within the first 12 seconds. ${ }^{3}$ It saves so little time. Most patients will tell their story in 2 minutes or less. ${ }^{4}$ Moreover, listening demonstrates the doctor's respect and concern. It involves more than the auditory nerve; intentional listening requires eye contact, the interpretation of body language, and positioning oneself so that both pairs of eyes are level.

\section{Touch}

A careful physical examination often provides invaluable clues to the correct diagnosis. Even when an examination is unnecessary, its performance conveys a commitment to thoroughness. Touching establishes a physical connection and sense of intimacy between the doctor and patient that invites communication and reassures the patient that there is no need to conceal or loathe their wounded part.

\section{Look}

Much of the patient's time at the doctor's office is consumed by waiting and then is delegated to otherssecretaries, medical assistants, mid-level practitioners, scribes. Though this delegation allows physicians to practice "at the top of their license," it subtracts from the time it takes to get to know their patients and earn their trust. With whatever time remains, it is imperative that the doctor look at the patient and not at the computer, smart phone, or clock.

\section{PLAN}

After taking a history, performing a physical examination, and making an assessment, the doctor then outlines the specific steps that will lead to the patient's recovery. Though we recognize that the plan is a tentative and educated guess, patients cling to it like a life preserver, relieved that a doctor is holding the rope that will pull them from their pain, uncertainty, and fear. A plan is never more necessary than when patients lack a definitive diagnosis or clear prospects for recovery. And although patients want to be involved in creating the plan, most are happy to leave the final decisions to their doctor. ${ }^{5}$

My neighbors needed to know why their son was sick, when his symptoms would abate, and what signs might signal a setback in his recovery. Plans should also identify the costs, risks, markers, and likelihood of success. The most important plan is often the one we keep in the back of our minds.

\section{Follow-up}

Even when doctors arrive at a brilliant diagnosis or offer cutting-edge cures, the job isn't done. We must also prepare patients with a prognosis, provide test results, and guide them through the travails of their illness. Much goes on after an office visit to assure that this happens. On a typical day, primary care doctors will see 18 patients whom they can bill. But they will also initiate, return, or review more than 90 telephone calls, e-mail messages, prescription refills, laboratory results, imaging reports, and outside consultations. ${ }^{6}$

Medicine is a performing art, and so it is that on some days our actions disappoint. What recourse do disgruntled patients have? Some will leave their doctor, though departures are rarely noticed and relocation offers no guarantees. Some will file a complaint or initiate a lawsuit, but their cases are almost always settled out of court, dismissed, or decided in favor of the defendant. ${ }^{7}$ Patients have come to expect professional interactions that are scrubbed of warmth, personal attention, and effective communication, and that is sad. Reform, when it comes, often hinges on patients' initiative-a letter of complaint or an arranged meeting with the doctor or office manager, but they should know that their doctor wants to be understood and respected as badly as they do.

The parents of the boy did not expect me to diagnose his problem right away (though they assuredly 
wished I had). But they had reason enough to thank me for their son's recovery, as their card of thanks conveyed:

We are writing to express our gratitude for making yourself so available when [our son] was sick. It was a trying time, but it would have been far worse had we no one to turn to. We consider ourselves especially fortunate to live in a community where our family doctor cares so much about the health and well-being of our children....

Many physicians receive such notes, but not for their medical prowess (which, again, is expected, and not easily judged) but for their compassion-for actions that arise out of love and kindness, not duty and fear. Patients want their doctor to listen longer and allow them to express themselves in their own words. They want doctors who care about the outcome-the patient's personal outcome, not just the clinical course - even if, in bearing witness to it, doctors will absorb their distress (what Anatole Broyard once described as "brooding"). ${ }^{8}$ Patients want to know that there is way out of their loneliness, confusion, panic, and pain. Most are not demanding perfection. Not cure. Not even relief, no matter what the TV commercials promise or how badly they wish them to be true. What we all desire is a plan that connects us to another human being_our doctor-which is a kind of relief all its own. Patients come to us for conversation, friendship, and hope, trusting in this well-worn path to recovery.

David Loxterkamp is the author of a new book, What Matters in Medicine: Lessons from a Life in Primary Care.
To read or post commentries in response to this article, see it online at http://www.annfammed.org/content/11/6/574.

Key words: doctor-patient relationship; communication; patient satisfaction

Submitted January 2, 2013; submitted, revised, March 18, 2013; accepted April 10, 2013.

\section{References}

1. Harris G. Who gets to be called a doctor? NY Times Well Blog. Oct 1, 2011. http://well.blogs.nytimes.com/2011/10/01/who-gets-tobe-called-a-doctor/.

2. Tannen D. Why sisterly chats make people happier. NY Times. Oct 25, 2011. http://www.nytimes.com/2010/10/26/health/26essay.html.

3. Rhoades DR, McFarland KF, Finch W, Johnson AO. Speaking and interruptions during primary care office visits. Fam Med. 2001;33(7): 528-532. http://www.interruptions.net/literature/Rhoades-FM01.pdf.

4. Langewitz W, Denz M, Keller A, Kiss A, Ruttimann S, Wössmer B. Spontaneous talking time at start of consultation in outpatient clinic: cohort study. BMJ. 2002;325:682-683. http://www.bmj.com/ content/325/7366/682.full.

5. Chung GS, Lawrence RE, Curlin FA, Arora V, Meltzer D. Predictors of hospitalised patients' preferences for physician-directed medical decision-making. J Med Ethics. http://jme.bmj.com/content/38/2/77. short.

6. Baron RJ. What's keeping us so busy in primary care? A snapshot from one practice. N Engl J Med. 2010;362:1632-1636. http://www. nejm.org/doi/full/10.1056/NEJMon0910793

7. Kane C. Medical liability claim frequency: a 2007-2008 snapshot of physicians. AMA Economic and Health Policy Research. August 2010.

8. Broyard A. Doctor talk to me. NY Times Book Rev. Aug 26, 1990. http://www.nytimes.com/1990/08/26/magazine/doctor-talk-to-me. html?pagewanted $=$ all $\delta$ src $=$ pm. 